\title{
Spatiotemporal Assessment of the Water Quality of the Hammam Boughrara Dam (North-West Algeria)
}

\author{
Belkheir Djelita ${ }^{1 *}$, Lotfi Benadda ${ }^{2}$ \\ 1 Research Laboratory Modeling Simulation and Optimization of Real Complex Systems, Ziane Achour \\ University of Djelfa, PO Box 3117, 17000 Djelfa, Algeria \\ 2 Laboratory of Valuation of water Resources, University of Tlemcen, Algeria \\ * Corresponding author's email: belkheirdjelita@yahoo.fr
}

\begin{abstract}
In this study, which contains a database covering the period from January 2008 to December 2010, on the water level of the Hammam Bougrara dam located in a semi-arid zone with moderate winter (western Algeria), we focused specifically on the mechanisms of eutrophication as well as the spatial and temporal variation of the physicochemical and biological characteristics of the reservoir. The diagnosis revealed high concentrations of certain elements such as $\mathrm{P}, \mathrm{PO}_{4}, \mathrm{NO}_{3}, \mathrm{NO}_{2}, \mathrm{NH}_{4}, \mathrm{Na}^{+}, \mathrm{Ca}^{2+}, \mathrm{Mg}^{2+}, \mathrm{K}^{+}, \mathrm{Cl}, \mathrm{HCO}_{3}^{-}$and $\mathrm{SO}_{4}^{-2}$, which characterizes highly mineralized waters with conductivities between 1100 and $1800 \mathrm{~S} / \mathrm{cm}$, therefore polluted and selenitic. These waters are rich in nutrients, such as phosphorus and with a slightly alkaline $\mathrm{pH}$ (between 7.1 and 9.1) favor the proliferation of organisms such as Chlorophyceae, Cyanophyceae and Diatomophycéeswhich together account 93 $57 \%$ of the population of algae. This proliferation causes a decrease in transparency and dissolved oxygen which are also signs of eutrophication. This study will adopt a better methodological approach to reduce the number of stations and increase the sampling rate, for a thorough understanding of limnology operation of the dam to ensure its protection. Despite the very high phosphorus inlakes during those years, the symptoms of eutrophication in the reservoir (chlorophyll a.) They are far from achieving the expected levels of extreme loads on the flow-replies Vollenweider. This could be explained by the fact that, upon his arrival for restraint, ortho-phosphate is quickly rendered inaccessible due to algae efficient flocculation means of fine clay particles and a formation hydroxyapatite followed by precipitation. Consequently, one can conclude that it would be necessary to develop and deepen our knowledge of limnology of lakes and reservoirs in temperate climates, especially in arid and semi-arid areas, in order to embed processes in these lakes a general model describing the relationship load-response, similar to that of Vollenweider. The results could help set specific objectives to reduce phosphorus inputs depending on the intended use of the waters and allow better management of water quality in terms of trophic response and in the context of sustainable development and decision support.
\end{abstract}

Keywords Hammam Boughrara Dam; pollution; eutrophication; phosphorus; modeling.

\section{INTRODUCTION}

The Hammam Boughrara Dam, located thirty kilometers from the city of Tlemcen (Algeria), was put into water in November 1998. This important work was built especially to ensure the supply of drinking water to the cities of Oran, Ain Timouchent, Maghnia and eventually Northwest corridors of the province of Tlemcen. This work will also serve the irrigation perimeters of the mean and bass Tafna.
Studies on water quality of the dam, conducted by the National Water Resources Agency (NWRA) have, since February 1999, revealed a deficiency of oxygen and since all the measurements confirmed the existence of an intense thermal stratification of water during the hot season, accompanied by deoxygenation of the hypolimnion for several months.

This degradation of water quality has seriously disturbed the exploitation of the Hammam Boughrara dam water treatment station. Thus, 
during the hypolimnion hypolimnion period when the water of the hypolimnion is rendered unusable, the abstractions are made from superficial layers rich in algals, and water treatment requires a large consumption of chlorine, the overdose of aluminum sulfate, and the use of powdered activated carbon to fight against tastes and smells.

Since 1999 and as part of a national project face the problem of eutrophication, NWRA has undertaken the study of the factors determining the water quality of the dam Hammam Bouhgrara. This study was completed and deepened by several series of comprehensive analyzes that we started in 2008. Some of the results have already been summarized and presented as communications and publications in national and international scientific journals.

Apart from the analytical work on the water quality of previously unsystematically performed water, there are no studies specifically addressing the mechanisms of eutrophication and spatiotemporal variations of the physicochemical and biological characteristics of the reservoir. In this study, the results cover the period including January 2008 to December 2010, our objectives are:

- Establish a diagnosis of the current state and characterize the spatial variability and temporal changes of the water quality of Hammam Boughrara dam in order to contribute to the knowledge of the evolution of this ecosystem.

- First, the objective is to establish a better understanding of the quantitative relationship between the intake of nutrients and the trophic response of our dam, on the other hand, to determine the impact of the morphology, hydrology and physicochemical characteristics of the trophic status of the dam.

- To stablish a scientific database, even systematic, for understanding the evolution of the interannual of water quality and therefore process of eutrophication. This database will help us develop a tank water conservation strategy.

\section{MATERIALS AND METHODS}

\section{Presentation of the study site}

The basin of the Oued Mouillah, which belongs to the watershed of the Tafna $\left(7245 \mathrm{~km}^{2}\right)$, regulated by the dam Hammam Boughrara and located in the extreme northwest of the province of Tlemcen (North West Algerian), occupies an area of $2650 \mathrm{~km}^{2}$ with a perimeter of $230 \mathrm{~km}$ (largely shared with Morocco). This basin is composed in its majority by the plains of Angad (located in Oujda Moroccan territory) and that of Zrigua (1ocated in Algerian territory Maghnia) (Fig. 1).

From a geomorphological point of view, the watershed of Oued Mouillah is characterized by a form medium elongated (compactness coefficient Gravilius 1.5), an index of global slope $\mathrm{Ig}=7.5 \%$. It consists of very heterogeneous zones formed by mountains (the mountains of northwest Traras and the mounts south of Tlemcen), plains and valleys. The slopes are generally very accentuated in the mountains (excess 20\%) and soft (0 to 10\%) on either side of the river. The maximum and average altitudes of the basin are 1430 and $746 \mathrm{~m}$, respectively. The Rock slope index is 0.11 and the

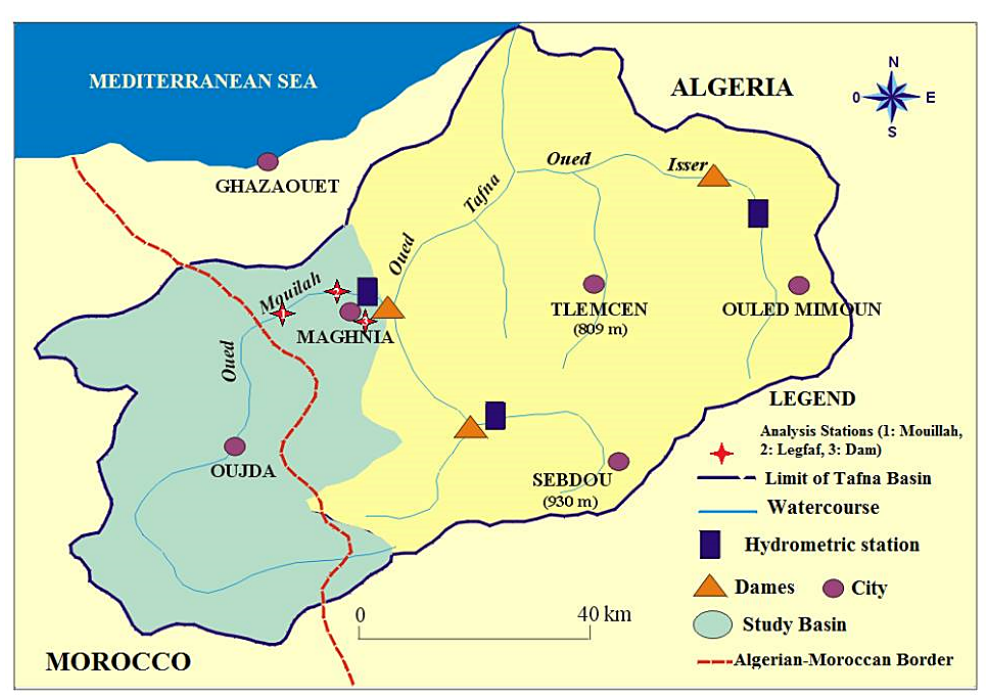

Fig. 1. Situation of the Oued Mouillah watershed 
drainage density is $0.16 \mathrm{~km} \cdot \mathrm{km}^{-2}$. The main watercourse with a length of $124 \mathrm{~km}$ and an average gradient of $8 \mathrm{~m} \cdot \mathrm{km}^{-1}$ originates in the region of El Abed, Algeria, at $1250 \mathrm{~m}$ altitude. It penetrates Morocco and takes the name Oued Sly and follows an intermittent course. It becomes permanent downstream near Oujda (Morocco) to call and enters Bounaim Oued in Algeria Maghnia at about under the name Oued Mouillah. It receives on its right bank of Oued Ouerdeffou which forms the meeting of Oueds Abbes and Mehaguin. The concentration time of the main stream is estimated at $\mathrm{Tc}=12$ hours, which means low speeds, which favors the decantation of solid particles in the water courses. Therefore, the runoff achieves the outlet of poor basin suspended matter.

The Oued Mouillah watershed is dominated by calcareous soils. Vertisols [Lufafa, 2003] that run along its main their principal thalweg and extend to north-east of the mountains of Traras and piedmonts the mountains of Tlemcen. It also contains shallow calcium formations (Luvisols) and alluvial marshland (fluvisols) developed in the northern part of the Maghnia plain. The southern part of the plain comprises red soils (arenosols) to crusting formed from saliferous marnes of the Miocene [Boubaya, 2017].

The watershed of Oued Mouillah is characterized by a semi-arid climate. The annual temperatures vary between 15.7 and $18.4{ }^{\circ} \mathrm{C}$ (period 1977-1995), with an average of $16.7^{\circ} \mathrm{C}$. Precipitations are relatively small and unevenly distributed during the year. Interannual average is $297 \mathrm{~mm}$ (period 1977-1995). The actual evaporation in open water at the confluence level of Oueds Mouillah and Tafna was estimated at about $1167 \mathrm{~mm}$ per year (Water Resources
Management). Of the basin area, 49\% generally consist of bare grounds located in its west part. In the rest of the basin, there are extensive cultivation ( $21 \%$ of the surface), a normal forest cover (14\% of the surface) and rangelands.

Based on a series of data, including accurate records for the period 1977-1995, the National Agency of Water Resources (NWRA) estimated that annual precipitation ranges between 465 and $173 \mathrm{~mm}$ and is subject to great variability interannually. $76 \%$ of annual rainfall is concentrated in the wettest period that lasts from November to April. The mean annual flow is estimated to total between 0.44 and $1.44 \mathrm{~m}^{3} / \mathrm{s}$. The highest flood was that of February 1979 with a peak flow estimated at about $264 \mathrm{~m}^{3} / \mathrm{s}$.

Registered specific annual sediment yields are mostly low, they vary between 17.3 and $1038.4 \mathrm{t}^{2}$.an $-\mathrm{km}^{1}$ (Table 1). Interannual average is $252.1 \mathrm{t} \mathrm{km}^{-2}$. $\mathrm{an}^{-1}$ [Benabdelmoumene and al, 2014]. This has resulted in a flow deficit of about $70 \%$ since the end of the 1970's [Amar and al, 2012]. In fact, it is emphasized that during the study period, the interannual runoff coefficient did not exceed $6 \%$ and that this basin is part of the Tafna that receives the least aggressive rains [Guenanou, 2019].

The dam at Hammam Boughrara, built up of water in 1998, is located at the confluence of the oueds and Tafna Mouillah. A capacity of 177 million $\mathrm{m}^{3}$, of which 59 million $\mathrm{m}^{3}$ are regularized and 23.30 million $\mathrm{m}^{3}$ constitute the dead volume. The area of its body of water varies from 2.5 to $4.8 \mathrm{~km}^{2}$, its average depth is $15 \mathrm{~m}$, and its maximum depth is $32 \mathrm{~m}$. The dam is designed mainly to meet the power needs for drinking water (AEP) in Oran cities (33 million $\mathrm{m}^{3}$ ) and

Table 1. Annual review of precipitation, liquid flows, sediment yield, runoff, and special damage. Station Sidi Belkheir (September 1986-August 1995) (NWRA, 2003)

\begin{tabular}{|c|c|c|c|c|c|}
\hline Year & $\begin{array}{c}\mathrm{P} \\
(\mathrm{mm})\end{array}$ & $\begin{array}{c}\mathrm{A}_{\llcorner} \\
\left(10^{6} \mathrm{~m}^{3}\right)\end{array}$ & $\begin{array}{c}\mathrm{A}_{\mathrm{S}} \\
\left(10^{6} \mathrm{t}\right)\end{array}$ & $\begin{array}{c}\mathrm{E} \\
(\mathrm{mm})\end{array}$ & $\begin{array}{c}\mathrm{A}_{\mathrm{SS}} \\
\left(\mathrm{km}^{-2} \cdot \mathrm{an}^{-1}\right)\end{array}$ \\
\hline $1986 / 87$ & 393.9 & 97.6 & 2.752 & 36.8 & 1038.4 \\
\hline $1987 / 88$ & 187.4 & 17.7 & 0.234 & 6.7 & 88.4 \\
\hline $1988 / 89$ & 270.8 & 48.4 & 0.282 & 18.3 & 106.3 \\
\hline $1989 / 90$ & 289.1 & 59.9 & 1.237 & 22.2 & 466.7 \\
\hline $1990 / 91$ & 357.9 & 58.8 & 0.844 & 23 & 318.4 \\
\hline $1991 / 92$ & 442.5 & 40.7 & 0.463 & 15.4 & 174.6 \\
\hline $1992 / 93$ & 246.3 & 14.1 & 0.046 & 5.3 & 17.3 \\
\hline $1993 / 94$ & 271.1 & 19.4 & 0.086 & 31.7 & 32.4 \\
\hline $1994 / 95$ & 263.4 & 40.5 & 0.07 & 15.3 & 26.4 \\
\hline Moyenne & 302.49 & 44.12 & 0.67 & 19.41 & 252.10 \\
\hline
\end{tabular}

Note: $\mathrm{P}$ - precipitation; AL - fluid intake; AS - solid contribution; E - the surface flow; SSA - specific solid intake 
Maghnia (17 million $\left.\mathrm{m}^{3}\right) .9 \mathrm{hm}^{3}$ are provided for irrigation. It should be noted that before the dam was built, no ecological studies have been performed to predict the development of the water quality of the reservoir to be created. As for the operation of the dam, monitoring was carried out during the period 1999-2011. The main results are shown in Table 2. Note that the contributions were calculated by hydrological year, i.e from September to August.

\section{Data and methods}

All samples were taken thanks to motorized watercraft at six stations (Fig. 2). The water was removed using bottles of Van Dron containing a thermometer. In general, samples were taken in the late morning or early afternoon. In summary, the following analytical methods were used for the various parameters:

- For the coring of sediment, a weight provided with plastic tubes $(1 \mathrm{~cm}$ in diameter) was used.

- Transparency of water: Secchi disk depth (diameter $39 \mathrm{~cm}$ );

- The PH, temperature, dissolved oxygen, alkalinity and electrical conductivity were measured immediately after collection of the sample water using a type of multi-parameter device WTW Multiline P3 PH / LF-SET.

Chemical elements, $\mathrm{Ca}, \mathrm{Mg}, \mathrm{Na}, \mathrm{SO}_{4}, \mathrm{~K}, \mathrm{Cl}$, $\mathrm{HCO}_{3}, \mathrm{NO}_{3}, \mathrm{NO}_{2}, \mathrm{NKH}, \mathrm{NH}_{4}, \mathrm{PO}_{4}$, and $\mathrm{P}_{\text {tot }}$, were analyzed using colorimetric dosage methods using a spectrophotometer.
- The total suspended solids were filtered through $\mathrm{GF} / \mathrm{C}$ glass fiber, followed by drying at $105^{\circ} \mathrm{C}$ and weighing. The organic fraction was determined after heating at $550^{\circ} \mathrm{C}$ [Rodier, 1966].

- The identification and enumeration of species were carried out using an inverted microscope Zeiss-type winkelselon according to the method of Utermöhl [1958], modified by Charteris and Kelly [1996].

- the dosage of the chlorophyll was performed according to the method Neveux [1988].

- To calculate the nutrient load ( $\mathrm{P}, \mathrm{PO}_{4}$ and $\left.\mathrm{NO}_{3}\right)$ and total suspended solids (TSS),

The two main tributaries that feed the reservoir, with regular sampling twice a month were carried out since January 2008. This frequency has increased, particularly during the floods of 7 to 9 March 2008 and 27 to 30 January 2009, when samples were taken every 3 to 4 hours. For flow measurement at the time of sampling, the nearest gauge point of each of the sampling points was used.

\section{RESULTS AND INTERPRETATION}

\section{Liquid and solid inputs for restraint}

Liquid intake Figure 3 (a) shows the variation in water odds for the period 2008-2010 (the indicated odds are each mid-month) where the level of the water fluctuates between a maximum of $298.7 \mathrm{~m}$ (NGA) and a minimum of $289.1 \mathrm{~m}$.

Table 2. Location of the Hammam Boughrara dam exploitation in 1999-2011 (source: National Agency for Dams and Transfers, NADT)

\begin{tabular}{|c|c|c|c|c|c|c|c|c|c|}
\hline \multirow[t]{2}{*}{ Years } & \multirow{2}{*}{$\begin{array}{l}\text { Pluviometry } \\
(\mathrm{mm})\end{array}$} & \multirow{2}{*}{$\begin{array}{l}\text { Affluent } \\
\left(\mathrm{Mm}^{3}\right)\end{array}$} & \multicolumn{2}{|c|}{$\begin{array}{c}\text { Consommation -AEP } \\
\qquad\left(\mathrm{Mm}^{3}\right)\end{array}$} & \multirow{2}{*}{$\begin{array}{l}\text { Irrigation } \\
\left(\mathrm{Mm}^{3}\right)\end{array}$} & \multirow{2}{*}{$\begin{array}{l}\text { Let loose } \\
\qquad\left(\mathrm{Mm}^{3}\right)\end{array}$} & \multirow{2}{*}{$\begin{array}{l}\text { Leak } \\
\left(\mathrm{Mm}^{3}\right)\end{array}$} & \multirow{2}{*}{$\begin{array}{l}\text { Evaporation } \\
\qquad\left(\mathrm{Mm}^{3}\right)\end{array}$} & \multirow{2}{*}{$\begin{array}{c}\text { Distributary } \\
\qquad\left(\mathrm{Mm}^{3}\right)\end{array}$} \\
\hline & & & Oran & Maghnia & & & & & \\
\hline 1999-2000 & 215.0 & 11.593 & - & - & 8.958 & - & 0.01 & 3.663 & 12.612 \\
\hline 2000-2001 & 238.6 & 36.651 & 8.888 & - & 9.626 & - & 0.014 & 4.681 & 23.208 \\
\hline 2001-2002 & 308.6 & 43.917 & 39.75 & - & 9.273 & 0.324 & 0.03 & 4.569 & 53.946 \\
\hline 2002-2003 & 293.6 & 38.150 & 31.98 & - & 1.916 & 0.027 & 0.036 & 4.173 & 38.132 \\
\hline 2003-2004 & 346.6 & 48.371 & 39.378 & - & 4.409 & 0.36 & 0.036 & 3.863 & 48.011 \\
\hline 2004-2005 & 229.3 & 15.202 & 6.044 & 0.342 & - & 1.023 & 0.036 & 3.441 & 12.196 \\
\hline 2005-2006 & 189.6 & 38.449 & 6.909 & 7.008 & - & 0.54 & 0.036 & 5.093 & 19.643 \\
\hline 2006-2007 & 253.0 & 32.325 & 1.992 & 6.49 & - & 0.343 & 0.045 & 6.252 & 15.122 \\
\hline 2007-2008 & 203.0 & 30.120 & 4.465 & 3.21 & - & 0.087 & 0.026 & 3.834 & 16.422 \\
\hline 2008-2009 & 224.0 & 50.074 & 7.24 & 7.367 & 9.013 & 0.232 & 0.021 & - & 19.126 \\
\hline 2009-2010 & 321.3 & 54.534 & 6.21 & 8.21 & 8.887 & 1.981 & 0.068 & - & 57.652 \\
\hline 2010-2011 & 286.6 & 28.872 & 8.13 & 7.91 & 8.094 & 0.867 & 0.044 & - & 22.168 \\
\hline
\end{tabular}




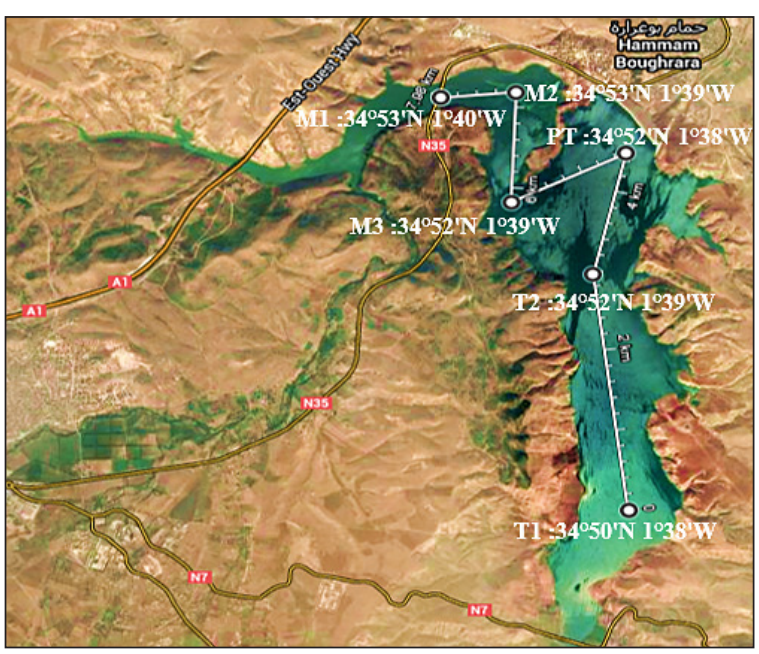

Fig. 2. Dam Hamme Boughrara with sampling points

As in Figure 3 (b), it appears that the intakes distributed very unequally over the year, take place mainly in winter during periods of flooding. Indeed, the biggest floods in the period 2008-2010 took place in December 2008 and January-February 2009 , where about 56 million $\mathrm{m}^{3}$ were recorded. This means, theoretically, that the useful volume of the reservoir has been renewed one and a half times during this short period of three months. The peak rate in January was estimated at about $54 \mathrm{~m}^{3} / \mathrm{s}$. This single belief has provided only $51 \%$ of the liquid intake of 2009 , with a relative contribution of the two oueds estimated at $77.4 \%$ for Mouillah and $22.6 \%$ for Tafna.

The use for the formula of the residence time of water TS $=$ V/Q (Q: debit in $\mathrm{m}^{3} /$ year; V: volume of the lake $\mathrm{m}^{3}$ ) reveals the following rates: $1.45 ; 0.87$ and 2.3 respectively for the years 2008 ;
2009 and 2010. It should be noted that intakes were calculated for a hydrological year.

Solid intakes. Total intakes for years 2008,2009 and 2010, and the inlakes for each subbasin are summarized in Table 3, which further gives the fraction of contributions during periods of flooding, where the flow is greater than $7 \mathrm{~m}^{3} / \mathrm{s}$.

It can be seen that during the rainy winters, almost all the sediment yield is provided by floods.

Nutrient loads per unit area. Phosphorus intakes for restraint were extremely high during those years. Even if one subtracts the portion of contributions having been immediately eliminated by the spillway at the time of the great flood (approximately 13\% of annual intakes liquids), we arrive at a total phosphorus intake by about 400 tons, which is equivalent to an annual phosphorus load in the reservoir of the order of $140 \mathrm{~g} / \mathrm{m}^{2}$.

If we apply the well-known relation of between phosphorus load and biological response in predicting the degree of eutrophication of the reservoir[Afshar, 2012], it almost falls outside the usual diagram, as the load is high. Even if we consider that a part of the phosphorus was incorporated in the mineral particles in suspension and therefore inaccessible to the algae, it still comes at a very high cost for the phosphorus load in solution (orthophosphate). It should be noted that the proportion of orthophosphate at the moment of the highest flow rates ranges from 60 to $\%$ and $90 \%$ of total phosphorus. However, symptoms of eutrophication in the reservoir (chlorophyll a) are very far from achieving the expected extreme levels and according to the load-response diagrams.

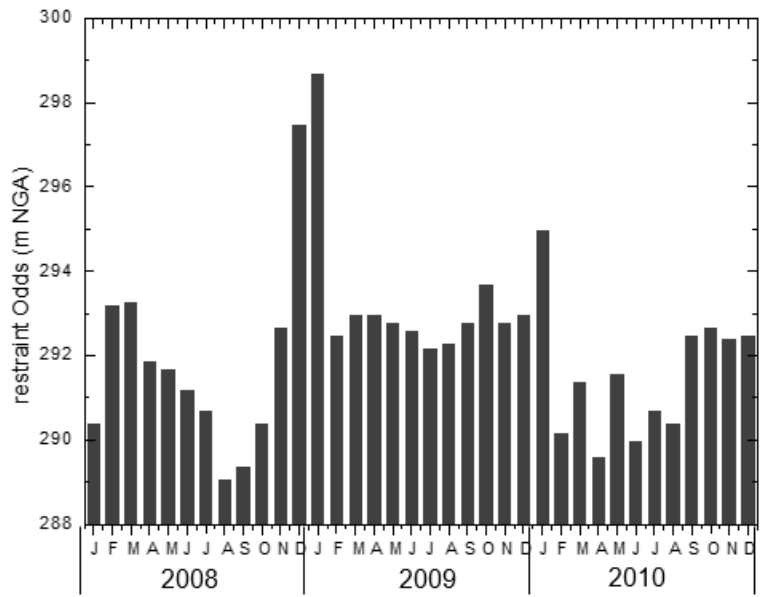

(a)

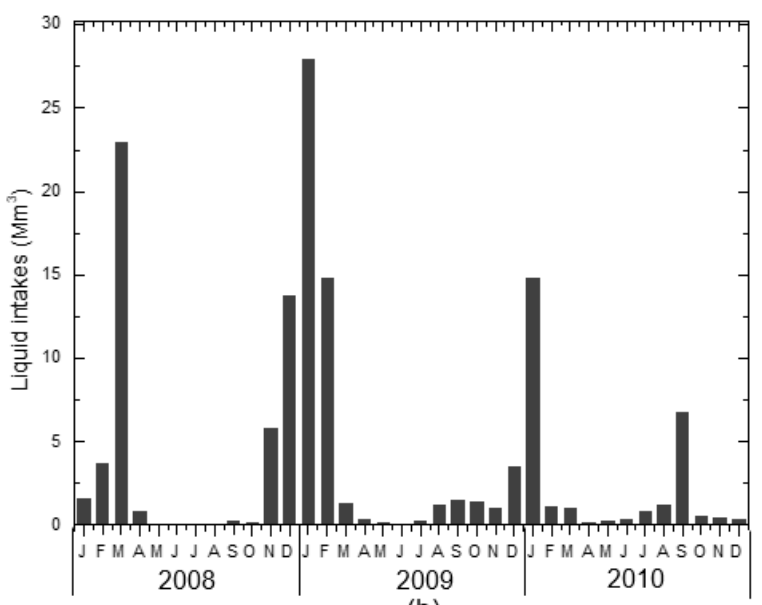

(b)

Fig. 3. (a) Variations of restraint Odds (b) monthly intakes liquids for restraint. Period: January 2008 to December 2010 
Table 3 Annual inlakes of total suspended solids and nutrient salts of the years 2008, 2009 and 2010

\begin{tabular}{|l|c|c|c|c|c|c|c|c|c|}
\hline \multirow{2}{*}{ Specification } & \multicolumn{3}{|c|}{ Mouillah } & \multicolumn{3}{c|}{ Tafna } & \multicolumn{3}{c|}{ Total } \\
\cline { 2 - 11 } & 2008 & 2009 & 2010 & 2008 & 2009 & 2010 & 2008 & 2009 & 2010 \\
\hline Liqu.Inlake.Mm ${ }^{3}$ & 39 & 46 & 19 & 11 & 8 & 10 & 50 & 54 & 29 \\
\hline$\%$ & 78 & 85 & 66 & 22 & 15 & 34 & 100 & 100 & 100 \\
TSS, tons & 1300 & 3440 & 380 & 700 & 1500 & 220 & 2000 & 4940 & 600 \\
\hline$\%$ & 65 & 80 & 63 & 35 & 20 & 37 & 100 & 100 & 100 \\
$\%$ in flood & 91.9 & 87 & 89 & 98.7 & 92 & 77 & 95.3 & 89.5 & 83 \\
$\mathrm{P}_{\text {tot }}$ tons & 112.5 & 136 & 54 & 37.5 & 48 & 13.5 & 150 & 184 & 67.5 \\
\hline$\%$ & 75 & 80 & 72 & 25 & 20 & 28 & 100 & 100 & 100 \\
$\%$ in flood & 89 & 97 & 67 & 81 & 84 & 57 & 85 & 90.5 & 62 \\
$\mathrm{NO}_{3}$-N, tons & 160 & 86 & 20 & 79 & 33 & 10 & 240 & 120 & 30 \\
\hline$\%$ & 67 & 72 & 66 & 33 & 28 & 34 & 100 & 100 & 100 \\
$\%$ in flood & 94 & 83 & 46 & 89 & 87 & 65 & 91.5 & 85 & 55.5 \\
\hline
\end{tabular}

\section{Limnological studies in retainer abiotic factor}

Studies on water quality. To get an idea of the differences (or similarity) of sampled water quality at the three stations (T2, PT and M3), a parameter representing stable quality, conductivity and dissolved oxygen was selected. After analyzing the results grouped on the same diagram, it was found that there were no significant differences between the three stations, in particular with regard to the hypolimnic water. Therefore, to facilitate the reading of this study, we will focus on giving only the results of the PT station, for which there is also the largest number of data.

Temperature, $\mathbf{p H}$. The water temperature varies usually between $10.9{ }^{\circ} \mathrm{C}$ and $31{ }^{\circ} \mathrm{C}$ with very similar temporal variations from one year to the other (Fig. 4 (a)). In February and March, the mass of homothermal water of about $13{ }^{\circ} \mathrm{C}$ begins to be heated and the thermal stratification is gradually established. Thus, the temperature of the epilimnion increases about $3{ }^{\circ} \mathrm{C}$ per

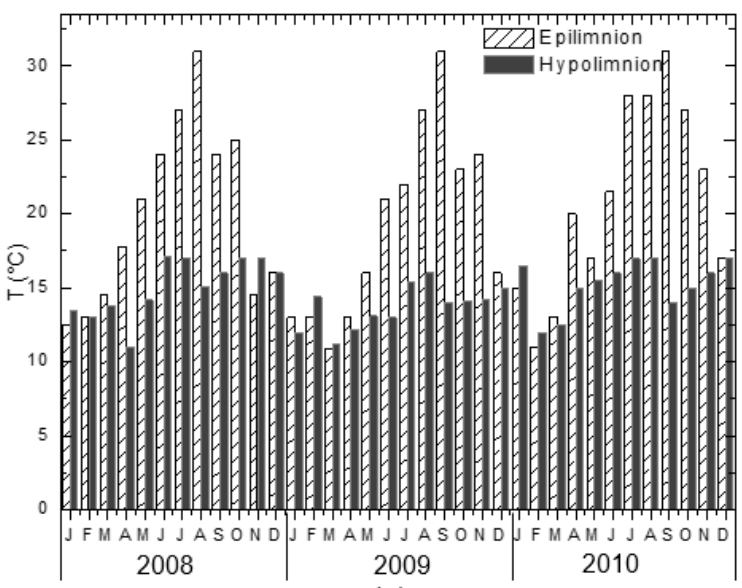

(a) month during spring and summer to reach its maximum towards the month of August. In the hypolimnion, the temperature slowly increases from $11-12{ }^{\circ} \mathrm{C}$ to $17^{\circ} \mathrm{C}$ in July; it then decreases by a few degrees, at the same time that the temperature in the epilimnion achieved its highest values. Between September and December, the temperature of the water rises hypolimnic yet, while that of water épilimnique down. Finally, from December to February, the water mass is homothermically cooled with temperatures ranging from 17 to $11-12{ }^{\circ} \mathrm{C}$.

The main factors causing the variation of the water temperature are sunlight and evaporation, which are unstable throughout the year. The variations of liquids intakes relatively little influence the temperature of the water at the PT station. The only obvious effect of the significant contributions of March 2004 on the thermal balance was delayed a few weeks the lowering of the temperature of the water hypolimnic to a minimum.

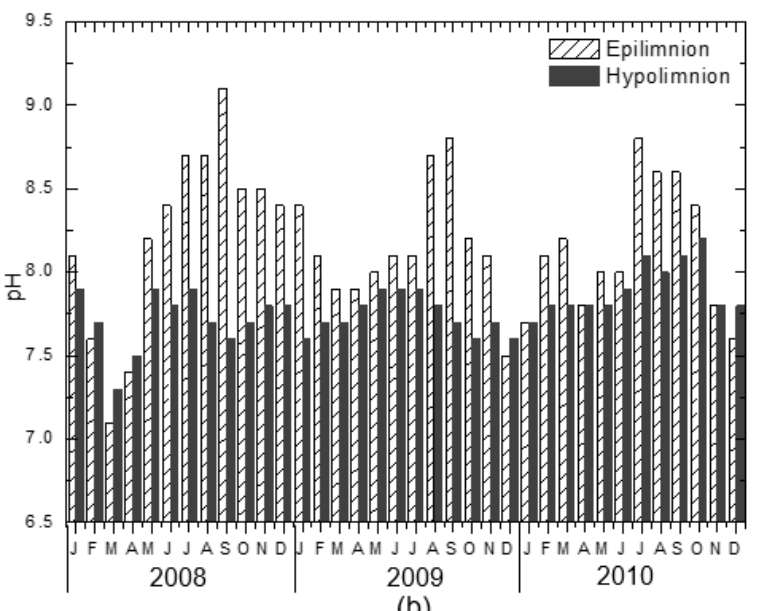

(b)

Fig. 4. Evolution in the temperature of time (a), pH (b) at the PT station. Period January 2008 to December 2010 
The $\mathrm{pH}$ also presents regular variations from one year to another. In the epilimnion, the values fluctuate between 8 and 9.1 in the middle of the summer and fall to about 7.1 during the winter (Fig.4 (b)). The $\mathrm{pH}$ varies mainly according to the assimilation of $\mathrm{CO}_{2}$ by phytoplankton [Shchapov et al., 2021]. Thus, it was measured as 9.1 maximum $\mathrm{pH}$ values at the surface of the retainer at the moment of significant algal blooms.

Transparency of the water, suspended solids. The parameters that are more or less directly related to the degree of light penetration in the water are the Secchi depth (SD), total suspended solids (TSS) and turbidity measured using a turbidity meter [West and Scott 2016].

The evaluation of transparency is a simple global measure of the trophic evolution of the reservoir. The SD varies between $0.2 \mathrm{~m}$ and $4.5 \mathrm{~m}$ in the reporting period, with the lowest values recorded in March 2008, December 2008, January-February 2009 and January 2010 and just after the great flood. The highest values coincide on the one hand, with the relatively low liquid intakes, on the other, with the period of non-phytoplankton (non floration). Thus, we see that transparency is influenced by contributions exceeding 8 million $\mathrm{m}^{3}$ (Fig. 5 (a)).

The values of TSS are generally less than $30 \mathrm{mg} / \mathrm{L}$, with the exception of those registered in the months of March 2008 and January-February 2009 and which are most important to the respective values of the order of 65,103 and $80 \mathrm{mg} / \mathrm{L}$. This could be due to the major floods that occurred during this period (Fig. 5 (b)). The organic fraction of TSS varies throughout the year. During summer, this fraction can be estimated at 30-60\%

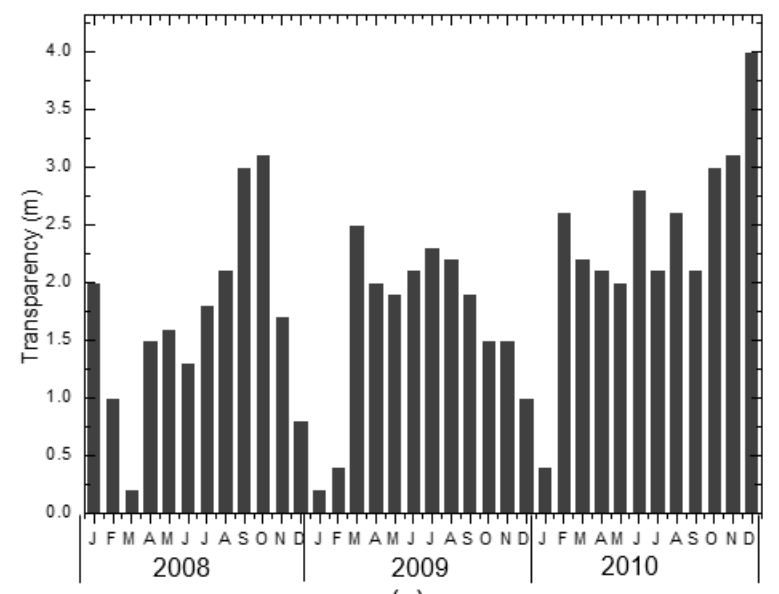

(a) of total TSS. We can conclude that fairly large for analytical errors undermine the reliability of the determinations of TSS.

On the contrary, the turbidity measurement is much more precise. The correlation between turbidity and $\mathrm{SD}$ is also more assertive [Harvey et al. 2014] $(\mathrm{R} 2=0.55)$ and the regression is described by the equation: $\mathrm{SD}(\mathrm{m})=-0.081+$ $\mathrm{x}$ JTU 3 14. However, no correlation was found between SS and SD.

Oxidizing materials. The two main oxidizing materials in the reservoir water are dissolved oxygen and nitrate. If these two forms of oxygen, free and chemically bound, are not present in sufficient quantities to meet the demand for oxidation of organic matter, another "donor" oxygen will be brought into play, namely sulfate, knowing that the action of this donor "harmful" of oxygen results in formation of hydrogen sulfide [Adam and al. 2011].

The amount of oxygen dissolved in the epilimnion generally varies between 3 and $9.5 \mathrm{mg} / \mathrm{L}$. However, extreme values were measured, namely 15.1 and $18 \mathrm{mg} / \mathrm{L}$, respectively, for the months March 2008 and March 2010. This corresponds to the time of strong ventilation of surface water by the mechanical action of the wind. Low values, less than $2 \mathrm{mg} / \mathrm{L}$, are registered in the brewing time (Fig. 6 (a)). The dissolved oxygen in the hypolimnion decreases rapidly during the stratified period. Almost every year, there is the presence of anaerobic conditions at least towards the end of summer.

The maximum concentrations of this fraction of total nitrogen are entirely determined by inlakes from outside. Important intake liquids

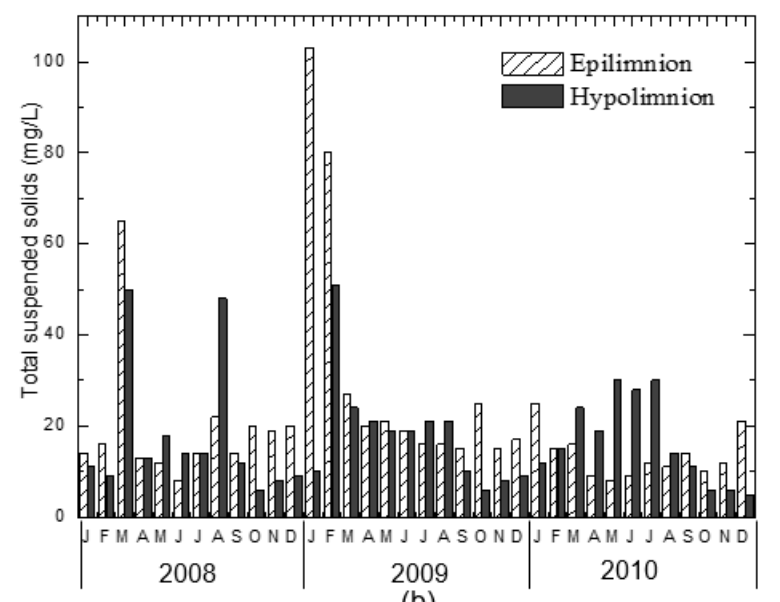

(b)

Fig. 5. Time changes the depth of the Secchi disc (a) and Total suspended solids (b) at the PT station. Period January 2008 to December 2010 


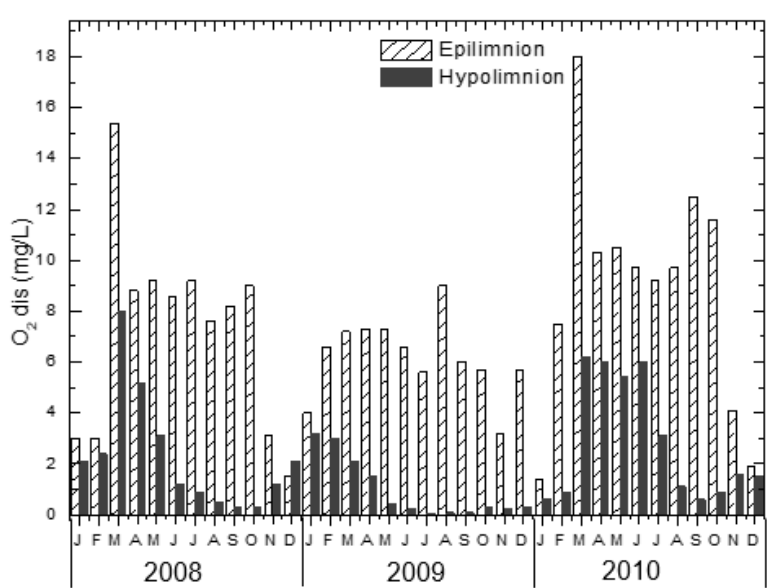

(a)

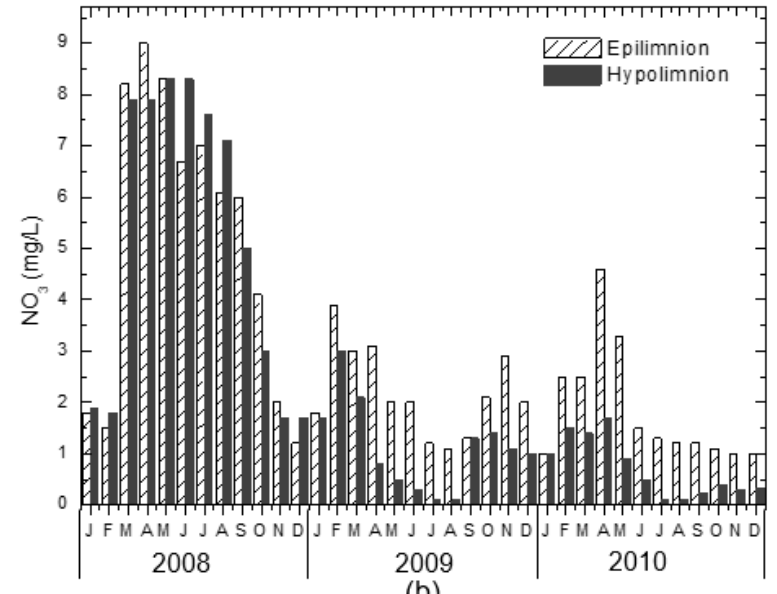

(b)

Fig. 6. Evolution in time of the concentration of dissolved oxygen (a) and nitrates

(b) at the PT station. Period January 2008 to December 2010

from March 2008 have generated NO3 concentrations of approximately $9 \mathrm{mg} / \mathrm{L}$, while relatively small contributions to the spring of 2009 and 2010 resulted in $\mathrm{NO}_{3}$ concentrations between 1 and $4.6 \mathrm{mg} / \mathrm{L}$ only. During spring and summer of 2009 and 2010, nitrate, as well as hypolimnion, progressively exhausted, while in autumn 2010, low concentrations of nitrate in water could still be detected (Fig. 6 (b)).

Nutrient salts. Although nitrates obviously are part of nutrients, we preferred to treat them from oxidizing materials, because they probably play a primary role in the restraint. We will now study the phosphorus and ammonium.

A total phosphorus concentration are extremely high and varies between 0.25 and $3.85 \mathrm{mg} / \mathrm{L}$ with an average of $1.91 \mathrm{mg} / \mathrm{L}$. These high levels are due to industrial discharges, including those containers detergents. The maximum peaks recorded during the periods immediately following the great flood.

Table 4. Results of the analysis of different nitrogen fractions in the epilimnion

\begin{tabular}{|l|c|c|}
\hline \multirow{2}{*}{ Fraction } & \multicolumn{2}{|c|}{ Concentrations (mg/L) } \\
\cline { 2 - 3 } & Averages & Maximum \\
\hline $\mathrm{N}$ inorganic & 5.69 & 14.6 \\
\hline $\mathrm{NO}_{3}$ & 3.07 & 9.0 \\
\hline $\mathrm{NO}_{2}$ & 0.87 & 1.33 \\
\hline $\mathrm{NH}_{4}$ & 1.75 & 4.26 \\
\hline $\mathrm{N}$ organic & 0.50 & 1.1 \\
\hline $\mathrm{N}$ total & 6.19 & 15.7 \\
\hline
\end{tabular}

Figure 7 (a) shows an increase of the concentration of orthophosphate in the water of the hypolimnion during the anaerobic period from August to December, which could be due to some remobilization that already incorporated in the nutrient sediment. But in épilimnique water during the productive season (spring-summer), orthophosphate levels are generally relatively low compared to the study values recorded during the years of the study, and fluctuate between 1.75 and $0,19 \mathrm{mg} / \mathrm{L}$.

With regard to the concentrations of ammonium, it is found that the contents are generally very high. The peaks recorded during the study period were approximately $4.26 \mathrm{mg} / \mathrm{L}$ in the epilimnion and $4.33 \mathrm{mg} / \mathrm{L}$ in the hypolimnion (Table 4). There was also a net increase of the ammonium content during the autumn, which coincides with the mineralization of organic matter sedimented (Fig. 7 (b)). The concentration of ammonium gradually decreases during the period of highest production in the epilimnion until values lower than $0.5 \mathrm{mg} / \mathrm{L}$ by the end of summer.

Conductivity. The conductivity and consequently the dissolved solids of the water of the reservoir show an annual cycle determined by liquid inputs from oueds. In addition to cyclical variation, there is a very clear trend towards increasing the conductivity during prolonged dry periods. The great flood in January 2009 caused a relative reduction in the conductivity of reservoir water to $1100 \mu \mathrm{s} / \mathrm{cm}$. Or, they were measured at high values in $1800 \mu \mathrm{s} / \mathrm{cm}$ for the month of August 2009. The determining causes of changes in 


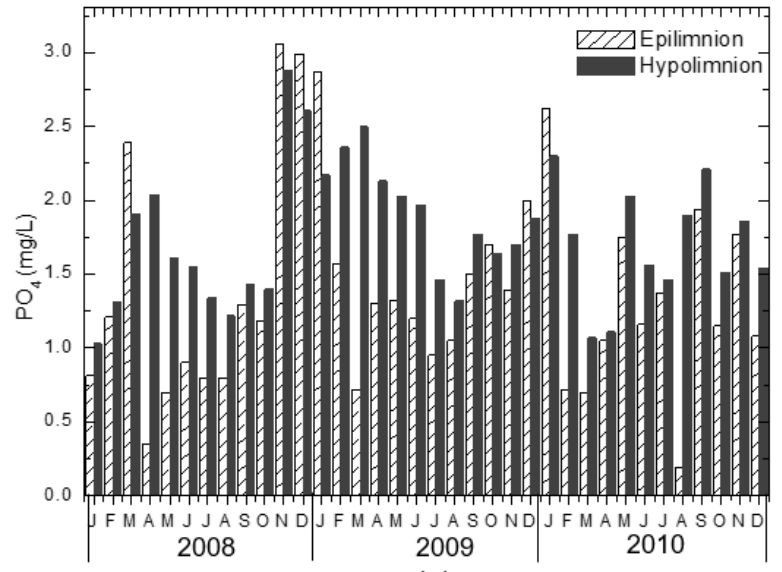

(a)

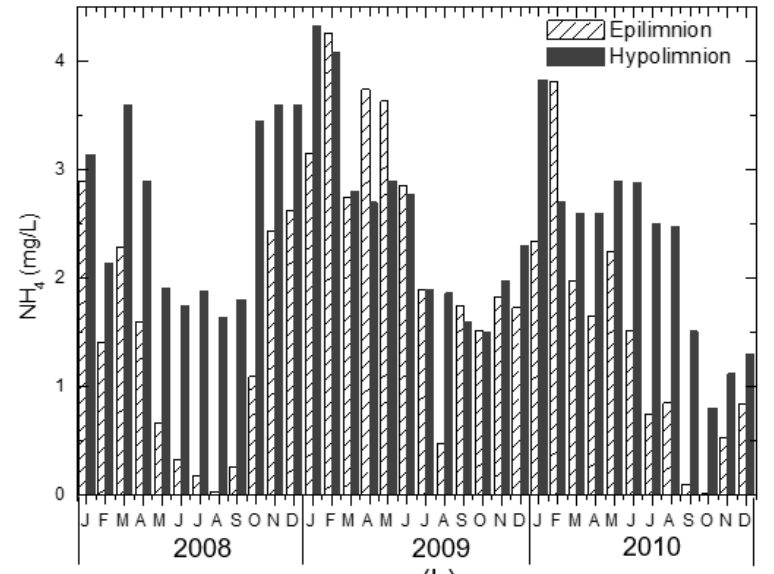

(b)

Fig. 7. Evolution in time of the concentration of orthophosphate and ammonium at the PT station. Period January 2008 to December 2010

conductivity are first the origin and amount of water entering the reservoir and evaporation.

During major floods, almost all of the water provided by Oueds from surface runoff. This water consequently contains little leached from the soil salts. However, in dry periods, a large fraction of the water that enters the retention is coming from groundwater, which is rich in dissolved salts. For example, water of the conductivity values of the river Mouillah corresponding to different flow rates are shown in Table 5.

A long period of drought means that, on the one hand, a large part of the liquid intake, although quantitatively small, has had time to soak in the ground and become rich in dissolved salts; the result will be an increase in the conductivity in the water of the reservoir. On the other hand, he shows that evaporation also causes an increase in the salt concentration in the water. Our calculations indicate that during the summer of 2010 the evaporation would be responsible for about $20 \%$ of the increase of the conductivity (60 microseconds / $\mathrm{cm}$ per month). This contribution is obviously more important in the epilimnion than in the hypolimnion.

Table 5. Values of the water conductivity of Oued Mouillah corresponding to different flow rates.

\begin{tabular}{|c|c|}
\hline Debit $\left(\mathrm{m}^{3} / \mathrm{s}\right)$ & Conductivity $(\mu \mathrm{s} / \mathrm{cm})$ \\
\hline 18 & 560 \\
\hline 9 & 840 \\
\hline 2.4 & 1820 \\
\hline 0.11 & 2330 \\
\hline 0.06 & 3540 \\
\hline
\end{tabular}

The ions that contribute the most to the conductivity of river water are Mouillah $\mathrm{Na}^{+}$and $\mathrm{CI}^{-}$, it is precisely in this subbasin that we find a large underground water, while Oued Tafna water is relatively richest in $\mathrm{Ca}^{2+}, \mathrm{Mg}^{2+}$ and $\mathrm{SO}_{4}^{-2}$ (Table 6).

Study of the homogeneity of the mass of water. We have already found that the characteristic, having perhaps the greatest influence as well on the water quality of the reservoir than on the eutrophication process, is the diet stratification and mixing of the body of water. The tracing of curves in the form of isopleths, starting from our database, we were able to follow the time course depending on the depth of certain parameters and found that the dam is a Hammam Boughrara monomictique lake stratification thermal extending generally from April to December, which usually takes place the brewing entire mass of water. Thus, when the thermocline is formed at the beginning of April, it is located at a depth of 5 to $10 \mathrm{~m}$, and it migrates gradually between 10 and $15 \mathrm{~m}$ in June and below $15 \mathrm{~m}$ in September-October (Fig. 8).

The thermocline form a barrier which prevents the transport of well oxygenated water to the epilimnion 1'hypolimnion and this results in a deficiency of oxygen increasingly increased as and when the consumption of dissolved oxygen in water of the hypolimnion [Zouabi-Aloui, 2015]. The isopleth diagrams of oxygen and $\mathrm{pH}$ clearly show that these two water masses have little contact with each other during periods of stratification. 
Table 6. Average concentrations, minimum and maximum of the major ions that contribute to the conductivity of the water to the PT station. Period January 2008 to December 2010.

\begin{tabular}{|c|c|c|}
\hline \multirow{2}{*}{ Ion } & Average & Min-Max \\
\cline { 2 - 3 } & \multicolumn{2}{|c|}{$\mathrm{mg} / \mathrm{L}$} \\
\hline $\mathrm{Na}^{+}$ & 257.72 & $127-416$ \\
\hline $\mathrm{Ca}^{2+}$ & 77.75 & $43-115$ \\
\hline $\mathrm{Mg}^{2+}$ & 62.67 & $35-109$ \\
\hline $\mathrm{K}^{+}$ & 18.36 & $10-32$ \\
\hline $\mathrm{Cl}^{-}$ & 363.64 & $213-487$ \\
\hline $\mathrm{HCO}_{3}^{-}$ & 198.94 & $210-487$ \\
\hline $\mathrm{SO}_{4}^{-2}$ & 358.47 & $47-364$ \\
\hline
\end{tabular}

Limnological studies - Study of phytoplanktonic population. Biological studies in the dam Hammam Boughrara were concentrated on the phytoplanktons community, given that these organisms are the basis of all other existing trophic levels in the reservoir. In 2004the levies of water samples used for of the qualitative determination and enumeration of cells of phytoplankton were carried out on a regular basis by biologists NWRA. From 2008, these studies were complemented by quantitative determinations (biomass, chlorophyll a) and by measurements of primary production.

Spatiotemporal variation of the algal assemblage. The specific composition of phytoplankton is related to several factors: external factors mainly represented by climate fluctuations and changes in the load of nutrients and other clean internal lakes, such as the role of herbivores in the regulation of algal populations [Li et al., 2015].

Analysis of phytoplanktonic water data from the Hammam Boughrara dam relating to depths of $0.5 ; 1$ and $3 \mathrm{~m}$ showed that Chlorophyceae were dominated mainly by Closterium aciculare Monoraphidium contorum and occupy the most important place with a frequency of $59.62 \%$ in the microalgal assemblage in most summer samples. By cons, in spring periods, Chlorophyceae are represented by Monoraphidium, Pediastrum, eudorina, Staurastrum, Coenocystis, Glaucocystis, Haematococcus, and Ankistrodesmus Oocystis. The first five types are typical for eutrophic lakes (Fig. 9). Müller and Mitrovic [2015] found that nutrient availability constitutes the main factor that controls Chlorophyceae when light and temperature conditions are adequate.
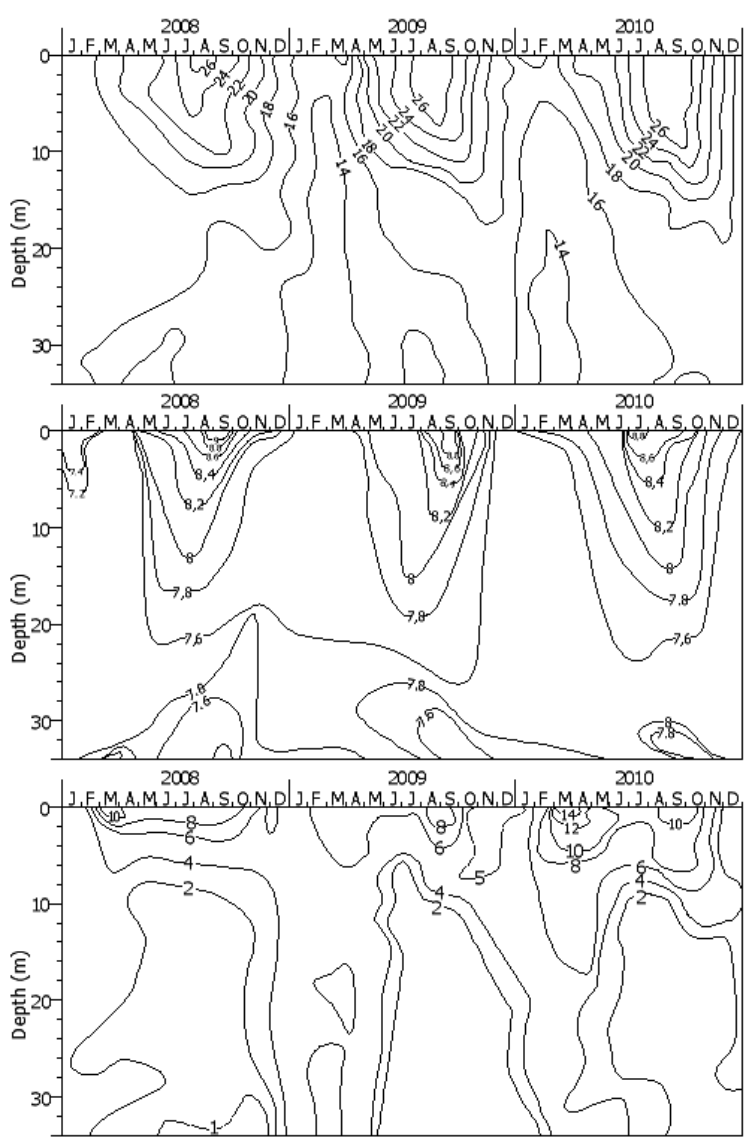

Fig. 8. Diagrams of isopleths: (a) temperature $\left({ }^{\circ} \mathrm{C}\right),(\mathrm{b}) \mathrm{pH}$, and (c) dissolved oxygen $(\mathrm{mg} / \mathrm{L})$ as a function of the depth to the PT station.

Period January 2008 to December 2010.

Variation of chlorophyll a. Chlorophyll a is an indicator of overall algal biomass, non-discriminating between the different groups of algae. It responds to nutrient loading and changes in the cell as a function of the environment. This is why the chlorophyll a is used to classify water bodies according to their trophic level [Deng and al, 2020]. In our case, the biomass was estimated using chlorophyll a doses in the water column comprised between the surface and the depth of $3 \mathrm{~m}$ (sometimes throughout the depth of the bottom surface).

The maximum chlorophyll a concentration values have reached $33.5 \mu \mathrm{g} / \mathrm{L}$ (in August 2008), $31 \mu \mathrm{g} / \mathrm{L}$ (July 2009), and $36.6 \mu \mathrm{g} / \mathrm{L}$ (in July 2010). Apart from these extreme values, the maximum concentrations in the water layer between 0 and $3 \mathrm{~m}$ depth varies between 1.2 and $24.12 \mu \mathrm{g} / \mathrm{L}$ during the period 2008-2010. During the producing seasons, the average values of the chlorophyll trophogène zone are between 17 and $19.3 \mu \mathrm{g} / \mathrm{L}$ (Fig. 10). 


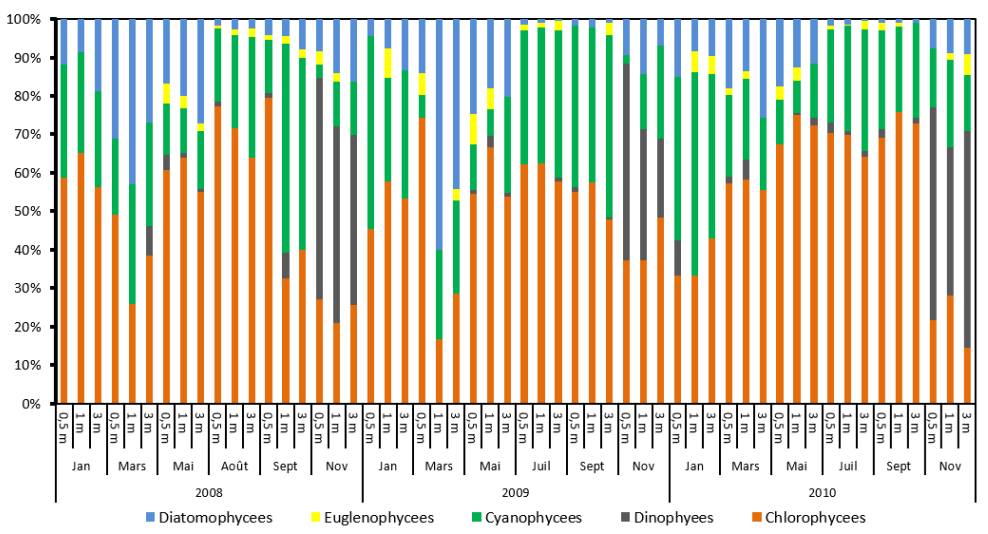

Fig. 9 Evolution of the total biomass of phytoplankton on the surface of the PT station. Period January 2008 to December 2010.

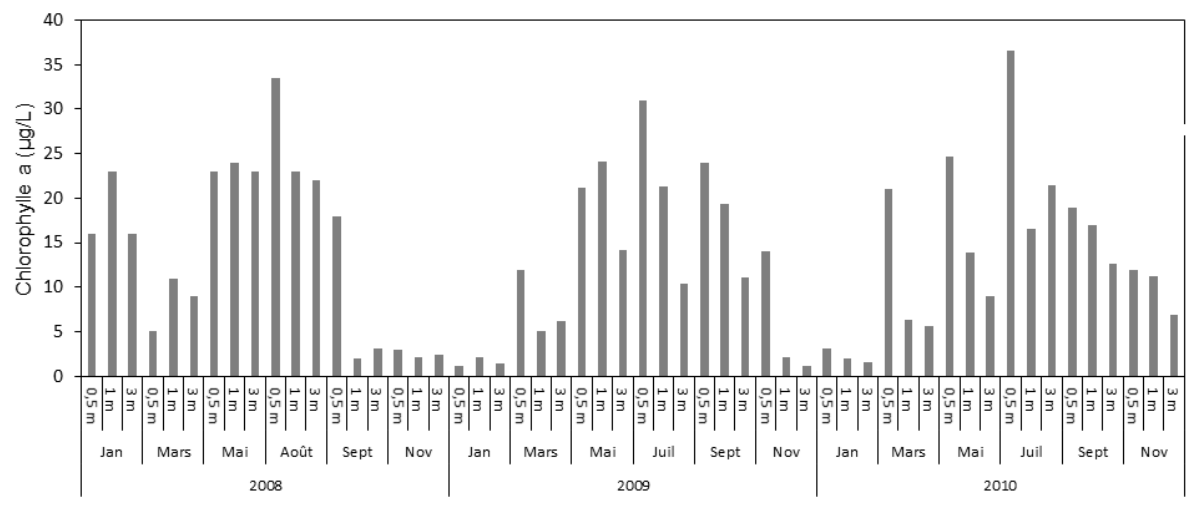

Fig. 10 The vertical distribution of chlorophyll a in the retainer in the PT station. Period January 2008 to December 2010.

\section{CONCLUSIONS}

In this study, which contains a database covering such the period from January 2008 to December 2010, we focused specifically on the mechanisms of eutrophication, as well as the spatial and temporal variation of the physicochemical and biological characteristics of the reservoir. The diagnosis of the current state of the dam Hammam Boughrara revealed high concentrations of certain elements such as $\mathrm{P}, \mathrm{PO}_{4}, \mathrm{NO}_{3}, \mathrm{NO}_{2}, \mathrm{NH}_{4}, \mathrm{Na}^{+}$, $\mathrm{Ca}^{2+}, \mathrm{Mg}^{2+}, \mathrm{K}^{+}, \mathrm{Cl}^{-}, \mathrm{HCO}_{3}^{-}$and $\mathrm{SO}_{4}^{-2}$, which characterizes highly mineralized waters with conductivities between 1100 and $1800 \mathrm{~S} / \mathrm{cm}$, therefore polluted and selenitic. These waters are rich in nutrients, such as phosphorus and with a slightly alkaline $\mathrm{pH}$ (between 7.1 and 9.1) favor the proliferation of organisms such as Chlorophyceae, Cyanophyceae and Diatomophycéeswhich together account $9357 \%$ of the population of algae. This proliferation causes a decrease in transparency and dissolved oxygen which are also signs of eutrophication. This study will adopt a better methodological approach to reduce the number of stations and increase the sampling rate, for a thorough understanding of limnology operation of the dam to ensure its protection.

Despite the very high phosphorus inlakes during those years, the symptoms of eutrophication in the reservoir (chlorophyll a.) They are far from achieving the expected levels of extreme loads on the flow-replies Vollenweider. This could be explained by the fact that, upon his arrival for restraint, ortho-phosphate is quickly rendered inaccessible due to algae efficient flocculation means of fine clay particles and a formation hydroxyapatite followed by precipitation. Consequently, one can conclude that it would be necessary to develop and deepen our knowledge of limnology of lakes and reservoirs in temperate climates, especially in arid and semi-arid areas, in order to embed processes in these lakes a general model describing the relationship load-response, similar to that of Vollenweider.

Contributions are distributed in a very uneven fashion throughout the year. Therefore, the 
evaluation of the residence time of water residence time, between 1.45 and 0.87 , reveals that large floods have renewed the dam waters one and a half times during the short 3 months. Using the correlation study conducted, we highlighted the existence of a logarithmic relation between exponentials: flow rates and TSS concentrations, and between flows and total phosphorus concentrations. This relationship allows predictions of approximate concentrations of TSS or phosphorus from the flow distribution during the rainy season.

The results could help to set specific objectives to reduce phosphorus inputs depending on the intended use of the waters and allow better management of water quality in terms of trophic answer and in the context of sustainable development and decision support. This work should be complemented by future work in order to make comparative analyzes with other plans of Algerian waters.

\section{REFERENCES}

1. Afshar, A., Saadatpour, M., \& Marino, M.A. 2012. Development of a complex system dynamic eutrophication model: application to Karkheh reservoir. Environmental Engineering Science, 29(6), 373-385.

2. Amar, Y., Djahed, B., Lebid, S., Anani, M., Moueddene, K., \& Mathieu, C. 2012. Impact of industrial pollution on the zooplankton population diversity of the Hammam Boughrara Dam. Journal of Environmental Science and Engineering. A, 1(4A).

3. Benabdelmoumene, F., Benabadji, N., Benchenafi, S., \& Benmensour, D. 2014. Research of the ecofloristic data into the contribution of groups to halophyte, Hammam Boughrara Area West Algeria. European Scientific Journal, 10(29).

4. Blakemore, J.D., Crabtree, R.H., \& Brudvig, G.W. 2015. Molecular catalysts for water oxidation. Chemical Reviews, 115(23), 12974-13005.

5. Boubaya, D. 2017. Combining resistivity and aeromagnetic geophysical surveys for groundwater exploration in the Maghnia plain of Algeria. Journal of Geological Research, 2017.

6. Charteris, W.P., Kelly, P.M., Morelli, L., \& Collins, J.K. 1997. Selective detection, enumeration, and identification of potentially probiotic Lactobacillus and Bifidobacterium species in mixed bacterial populations. International Journal of Food Microbiology, 35 (1), 1-27.

7. Deng, Y., Cheng, C., Feng, J., Liu, S., Ma, H., Chen, X., ... \& Guo, Z. 2020. Rapid environmental change shapes pond water microbial community structure and function, affecting mud crab (Scylla paramamosain) survivability. Applied microbiology and biotechnology, 104(5), 2229-2241.

8. Guenanou, F., Khelafi, H., \& Aattache, A. 2019. Behavior of perlite-based mortars on physicochemical characteristics, mechanical and carbonation: Case of perlite of Hammam Boughrara. Journal of Building Engineering, 24, 100734.

9. Harvey, G.L., Henshaw, A.J., Moorhouse, T.P., Clifford, N.J., Holah, H., Grey, J., \& Macdonald, D.W. 2014. Invasive crayfish as drivers of fine sediment dynamics in rivers: field and laboratory evidence. Earth Surface Processes and Landforms, 39(2), 259-271.

10. Li, Y., Liu, Y., Zhao, L., Hastings, A., \& Guo, H. 2015. Exploring change of internal nutrients cycling in a shallow lake: a dynamic nutrient driven phytoplankton model. Ecological Modelling, 313, 137-148.

11. Lufafa, A., Tenywa, M.M., Isabirye, M., Majaliwa, M.J.G., \& Woomer, P.L. 2003. Prediction of soil erosion in a Lake Victoria basin catchment using a GIS-based Universal Soil Loss model. Agricultural systems, 76(3), 883-894.

12. Müller, S., \& Mitrovic, S.M. 2015. Phytoplankton colimitation by nitrogen and phosphorus in a shallow reservoir: progressing from the phosphorus limitation paradigm. Hydrobiologia, 744(1), 255-269.

13. NADT (National Agency for Dams and Transfers), 2012. Technical Report on Water Leaks, Algeria: Algiers.

14. Neveux J., 1988. Extraction of chlorophylls from marine phytoplankton. Verh. Internat. Verein. Limnol., n²3, p. 928-932.

15. NWRA (National Water Resources Agency), 2003. Synthesis study on surface water resources in northern Algeria (Study report). Algeria: Algiers. 36 p.

16. NWRA (National Water Resources Agency), 2011. Monthly bulletins of surface water quality, Algeria: Oran..

17. Rodier, J. 1966. Chemical and physico-chemical analysis of water; natural water, waste water.

18. Shchapov, K., Wilburn, P., Bramburger, A.J., Silsbe, G.M., Olmanson, L., Crawford, C.J., ... \& Ozersky, T. 2021. Taxonomic and functional differences between winter and summer crustacean zooplankton communities in lakes across a trophic gradient. Journal of Plankton Research, 43(5), 732-750.

19. Utermöhl, H. 1958. Zur vervollkommnung der quantitativen phytoplankton-methodik: Mit $1 \mathrm{Ta}-$ belle und 15 abbildungen im Text und auf 1 Tafel. Internationale Vereinigung für theoretische und angewandte Limnologie: Mitteilungen, 9(1), 1-38.

20. Vollenweider, R.A. 1971. Scientific fundamentals of the eutrophication of lakes and flowing waters, with particular reference to nitrogen and phosphorus as factors in eutrophication. Paris: Organisation for economic co-operation and development.

21. West, A.O., \& Scott, J.T. 2016. Black disk visibility, turbidity, and total suspended solids in rivers: A comparative evaluation. Limnology and Oceanography: Methods, 14(10), 658-667.

22. Zouabi-Aloui, B., Adelana, S.M., \& Gueddari, M. 2015. Effects of selective withdrawal on hydrodynamics and water quality of a thermally stratified reservoir in the southern side of the Mediterranean Sea: a simulation approach. Environmental monitoring and assessment, 187(5), 1-19. 